\title{
Financing Decisions And Sustainability Of Family Business In Rwanda
}

\author{
Ndibwirende Jean Claude $^{1 *}$, Gasheja Faustin ${ }^{1}$, Ndikubwimana Philippe ${ }^{1}$ \\ 1 University of Rwanda - College of Business and Economics, Kigali-Rwanda \\ *The corresponding author's contact:
}

\begin{abstract}
Interested with family business, this study brings on board three relevant fields of research namely: financing decisions, family business and sustainability. Its purpose is to highlight the relationship between internal equity, external equity, debt financing decisions and family business sustainability. To examine this, we developed different theoretical models to test the influence of each financing decisions on the sustainability of family businesses with reference to six secondary cities of Rwanda. This study combines both quantitative and qualitative approaches and uses a sample of 54 selected family businesses operating in tourism industry. Data were collected using a structured questionnaire together with unstructured interview guide. The collected data were processed and analyzed using SPSS version 20. The results revealed that our main research question that financing decisions have an influence on family business sustainability was answered. Additionally, in Rwandan family businesses internal funds are highly used compared to external funds. The given reason is for not diluting the control of the family over the business. Family business in Rwanda tends to be in hands of restricted family members. When it comes necessary to outsource external funds, debt financing model is preferred and external equity financing model is exclusively ignored. To conclude, socio-emotional factors guide financing decisions in family business and this makes family business and non-family business to decide differently in terms of financing. In return, this influences the sustainability of family business. Family businesses in Rwanda are recommended to adopt sustainability practices to secure their continuity.
\end{abstract}

Keywords: Continuity; Debt financing; External equity financing; Family business; Internal equity financing. 